\title{
A MORTE NA CONCEPÇÃO DE ESTUDANTES DE ENFERMAGEM*
}

\author{
Francisca Patrícia Barreto de Carvalho', Raimunda Medeiros Germano², João Mário Pessoa Júnior ${ }^{3}$
}

\begin{abstract}
RESUMO: A morte se tornou este mal desconhecido que se agiganta diante dos homens e os desestabiliza, causando, muitas vezes, transtornos mentais irreversíveis quando se deparam com perdas familiares. Por isso mesmo, justificase estudá-la, pela possibilidade de promover a reflexão sobre o modo de levar a vida e de tratar os seres humanos na perspectiva da finitude. Este estudo teve como objetivo compreender o significado da morte para estudantes de Enfermagem; nessa perspectiva, foi desenvolvido dentro de uma dimensão qualitativa de abordagem fenomenológica. Para sua realização foram entrevistados dez estudantes durante o mês de julho de 2009. Emergiu, a partir das entrevistas, uma diversidade de sentimentos como medo, angústia, insegurança, fracasso, tristeza, de acordo com a experiência sensível de cada um. Para compreender as unidades de significado que emergiram do material empírico e que constituíram a essência da presente investigação, foram fundamentais os estudos de Heidegger, Bicudo, D’Assunção, Dastur, Morin, Boff, Kübler-Ross, Boemer, entre outros. A partir da compreensão do fenômeno estudado, pode-se afirmar que a morte produz sentimentos conflitantes que conduzem os estudantes à autoproteção. No entanto, estes mostraram-se sensíveis e receptivos à abordagem da morte dentro de outras dimensões, para além dos aspectos eminentemente técnicos. A pesquisa evidencia fragilidades na formação do enfermeiro no que concerne à compreensão do ser humano em sua totalidade e finitude, e a necessidade de superá-las.
\end{abstract}

PALAVRAS-CHAVE: Enfermagem; Educação em enfermagem; Morte.

\section{NURSING STUDENTS' UNDERSTANDING OF DEATH}

\begin{abstract}
Death has become an unknown evil, which towers over people and destabilises them, causing, often, irreversible mental harm when they are suddenly faced with family losses. For this reason alone it is justifiable to study it, for the possibility of promoting reflection on how one should lead one's life and treat people in the light of finitude. This study aimed to understand what death means for students of Nursing; which perspective led to a phenomenological approach with a qualitative dimension. It was carried out through interviews with ten students in July 2009. There emerged from the interviews a range of feelings such as fear, anguish, insecurity, failure and sadness, according to the experiences felt by each interviewee. To understand the units of meaning which emerged from the empirical data and which constitute the essence of this investigation, the studies of Heidegger, Bicudo, D’Assunção, Dastur, Morin, Boff, Kübler-Ross and Boemer, among others, were fundamental. From understanding the phenomenon studied, it can be affirmed that death produces conflicting emotions, which lead the students to self-protection. Nevertheless the students showed themselves to be sensitive and receptive to looking at death in dimensions other than those with simply technical aspects. The research showed weaknesses in the training of nurses in that which concerns the understanding of the human being in all its totality and finitude, and the necessity of overcoming these.
\end{abstract}

KEYWORDS: Nursing; Nursing education; Death.

\section{LA MUERTE EN LA CONCEPCIÓN DE ESTUDIANTES DE ENFERMERÍA}

RESUMEN: La muerte se volvió un mal desconocido que crece delante de los hombres, desestabilizándolos, causando, muchas veces, trastornos mentales irreversibles cuando hay pérdidas familiares. Por ese motivo, se justifica estudiarla, a causa de la posibilidad de promover la reflexión acerca del modo de vivir la vida y de tratar los seres humanos en la perspectiva de la finitud. Este estudio tuvo como objetivo comprender el significado de la muerte para estudiantes de Enfermería. En esa perspectiva, fue desarrollado bajo una dimensión cualitativa de abordaje fenomenológico. Para su realización fueron entrevistados diez estudiantes durante el mes de julio de 2009. Surgió, de las entrevistas, una diversidad de sentimientos, como miedo, angustia, inseguridad, fracaso, tristeza, de acuerdo a la experiencia sensible de cada uno. Para comprender las unidades de significado que surgieron del material empírico y que constituyeron la esencia de esta investigação, fueron fundamentales los estudios de Heidegger, Bicudo, D’Assunção, Dastur, Morin, Boff, Kübler-Ross, Boemer, entre otros. Por medio de la comprensión del fenómeno estudiado, es posible afirmar que la muerte produz sentimientos conflictantes que conducen los estudiantes a la autoprotección. Sin embargo, estos se mostraron sensibles y receptivos al abordaje de la muerte en otras dimensiones, para allá de los aspectos técnicos. La investigación evidencía fragilidades en la formación del enfermero acerca de la comprensión del ser humano en su totalidad y finitud, y la necesidad de superarlas. 
PALABRAS CLAVE: Enfermería; Educación en enfermería; Muerte.

${ }^{1}$ Enfermeira. Mestre em Enfermagem. Professora da Faculdade de Enfermagem Nova Esperança-FACENE Mossoró e da Universidade do Estado do Rio Grande do Norte-UFRN.

${ }^{2}$ Enfermeira. Pedagoga. Doutora em Educação. Professora do Curso de Graduação e do Programa de Pós-Graduação em Enfermagem/UFRN. Membro do Grupo de Pesquisa Ações Promocionais e de Atenção a Grupos Humanos em Saúde Mental e Saúde Coletiva/UFRN.

${ }^{3}$ Enfermeiro. Mestrando do Programa de Pós-Graduação em Enfermagem/UFRN. Bolsista CAPES/REUNI. Membro do Grupo de Pesquisa Ações Promocionais e de Atenção a Grupos Humanos em Saúde Mental e Saúde Coletiva/UFRN.

\section{Autor correspondente:}

Raimunda Medeiros Germano

Recebido: $29 / 09 / 10$

Universidade Federal do Rio Grande do Norte

Aprovado: 22/12/10

Lagoa Nova - 59.078-970 - Natal - RN

E-mail: rgermano@natal.digi.com.br 